\title{
Kadar Polifenol Total Ekstrak Etanol Kulit Buah Manggis (Garcinia mangostana) Pada Variasi Asal Daerah
}

Any Guntarti*

Fakultas Farmasi Universitas Ahmad Dahlan Yogyakarta

*Corresponding author: any_guntarti@yahoo.co.id.

\begin{abstract}
Background:Mangosteen peel is one of the waste of mangosteen, that nowadays have already utilized much to manage health problems. One of the ingredients in the mangosteen fruit skin is a polyphenols. Objective: to determine the polyphenols content of the ethanol extract of mangosteen peel variations based on different regions. Methods: Powder of dried mangosteen peel that come from 3 difference areas, Sumatera (Pekanbaru), Jawa (Yogyakarta) and Kalimantan (Martapura) extracted with ethanol $70 \%$ by multilevel maceration. Extract that obtained than tested specific parameter form of qualitative test of polyphenols compounds with $\mathrm{FeCl}_{3}, \mathrm{AlCl}_{3}$, ammonia vapor, Folin Ciucalteau and tannin test. Determination level of polyphenols (Gallic acid) with visible spectrophotometri after reacted with Folin Ciucalteau reagent. Results: The result of this research was quality test of extract etanol $70 \%$ Specific parameter test total phenol content ( $m g$ GAE/g ekstrak) from Sumatera, Jawa and Kalimantan are :824.13 (mg GAE/g ekstrak); 155,86 (mg GAE/g ekstrak); 688,9 (mg GAE/g ekstrak). Conclusions: There were difference in contents of polyphenol of mangosteen peel origin among Sumatera, Jawa and Kalimantan.

Keywords: mangosteen peel, specific parameters total poly phenol content, ethanol $70 \%$ extract
\end{abstract}

\begin{abstract}
Abstrak
Latar belakang: Kulit buah manggis sebagai salah satu hasil limbah buah manggis yang mulai banyak dimanfaatkan untuk mengatasi masalah kesehatan. Salah satu kandungan dalam kulit buah manggis adalah polifenol. Tujuan: untuk mengetahui kadar polifenol ekstrak etanol kulit buah manggis berdasarkan perbedaan variasi daerah. Metode: Serbuk kulit buah manggis kering yang berasal dari 3 daerah yang berbeda, yaitu Sumatera (Pekanbaru), Jawa (Kota Yogya) dan Kalimantan (Martapura) diekstraksi dengan etanol $70 \%$ secara maserasi bertingkat. Ekstrak yang diperoleh diuji parameter spesifik berupa uji kualitatif senyawa polifenol dengan $\mathrm{FeCl}_{3}, \mathrm{AlCl}_{3}$, uap amoniak, Folin Ciucalteau, dan uji tanin. Penetapan kadar polifenol (asam galat) dengan menggunakan spektrofotometri visible setalah direaksikan dengan pereaksi Folin Ciocalteau. Hasil: Uji kualitatif ekstrak etanol kulit buah manggis dengan pereaksi $\mathrm{FeCl}_{3}, \mathrm{AlCl}_{3}$, uap amoniak, Folin Ciucalteau, dan uji tanin menunjukkan hasil positif. Uji kuantitatif kadar senyawa fenol total (mg GAE/g ekstrak) dari Sumatra, Jawa dan Kalimantan, yaitu: 824.13 (mg GAE/g ekstrak); 155,86 (mg GAE/g ekstrak); 688,9 (mg GAE/g ekstrak). Kesimpulan: menunjukkan ada perbedaan kandungan senyawa polifenol ekstrak etanol kulit buah manggis daerah yaitu Sumatera, Jawa dan Kalimantan.

Kata Kunci: kulit manggis, parameter spesifik, kadar polifenol total, ekstrak etanol $70 \%$.
\end{abstract}




\section{Pendahuluan}

Tanaman manggis (Garcinia mangostana L.) merupakan tanaman yang hidup di lingkungan tropis dan mempunyai daya adaptasi luas (Factsheet, 2003). Di Indonesia, tanaman manggis tumbuh di daerah dataran rendah sampai ketinggian 600 meter dari permukaan laut (Pasaribu et al., 2012). Bagian tanaman manggis yang sering dimanfaatkan sebagai obat adalah kulit manggis yang memiliki kandungan kimia yang dapat menyembuhkan berbagai penyakit (Putra, 2010). Manggis merupakan tanaman buah berupa pohon berbatang kayu keras dan berasal dari kawasan hutan tropis basah yang teduh di kawasan Asia Tenggara (Ho et al., 2002). Manfaat dua senyawa santon $\alpha$-mangostin dan $\gamma$-mangostin diketahui memiliki aktivitas anti-inflamasi dengan menghambat produksi NO dan PGE2 (Lih et al., 2007). $\alpha$-mangostin, $\beta$ mangostin, dan garcinon B mempunyai aktivitas antimikroba (Munekazu et al., 2011; Nattaya et al., 1996). Kulit manggis diketahui mengandung senyawa santon sebagai antioksidan, antiproliferativ, dan antimikrobial yang tidak ditemui pada buah-buahan lainnya (Moongkarndi et al., 2008). Ekstrak etanol kulit buah manggis diketahui mengandung alkaloid, glikosida, steroid, flavonoid, polifenol, dan tanin yang bertanggung jawab dalam memberikan aktivitas farmakologi (Weecharangsan et al., 2013).

Dalam rangka menjamin mutu ekstrak agar kandungan kimia ekstrak dapat terjamin khasiatnya maka perlu dilakukan standarisasi mutu ekstrak yang terdiri dari paramater spesifik dan parameter non-spesifik (Dungir et al., 2012). Standarisasi ekstrak tumbuhan merupakan salah satu tahapan penting dalam pengembangan obat asli Indonesia yang mempunyai lebih dari 3000 jenis tumbuhan obat dan lebih dari 1000 jenis tumbuhan obat yang dimanfaatkan dalam industri obat tradisional (Anonim, 2008). Ekstrak tumbuhan obat dapat berupa bahan awal, bahan antara atau bahan produk jadi. Dengan adanya bahan baku terstandar dan proses terkendali, maka akan diperoleh produk atau bahan ekstrak yang mutunya terstandar (Anonim, 2000). Sampai saat ini standarisasi simplisia dan ekstrak kulit buah manggis (Garcinia mangostana L.) masih belum lengkap. Salah satu parameter mutu ekstrak secara kimia adalah kandungan senyawa aktif dalam ekstrak tersebut. Salah satu kandungan zat aktif yang perlu diuji adalah kadar polifenol total ekstrak etanol kulit buah manggis (Garcinia mangostana L.) berdasarkan perbedaan tempat tumbuh (Lee et al., 2003; Huang and Prior, 2005).

\section{BAHAN DAN METODE Bahan}

Bahan yang digunakan yaitu kulit buah manggis dari Jawa (Purworejo), Sumatera (Pakanbaru), Kalimantan (Martapura). Etanol teknis 70\% (Brataco) sebagai cairan penyari. Pada uji tabung menggunakan $\mathrm{FeCl}_{3}$ (Merck), gelatin, ammonia $\mathrm{P}$ (Merck) akuades, $\mathrm{NaCl} 2 \%$ (Merck), Bahan kimia yang digunakan pada penetapan kadar fenolik digunakan standar asam galat, larutan Folin Ciocalteu P (Merck KGaA 64271), dan larutan natrium karbonat (Na2CO3) p.a. (Merck KGaA 64271).

\section{Alat}

Alat yang digunakan pada penelitian ini adalah spektrofotometer UV-Vis (Shimadzu), pengaduk elektrik, corong Buchner, glassware (Pyrex), timbangan elektrik, ayakan bertingkat mesh 20, 30, dan 50, waterbath, oven, rotary evaporator (Heidolph), hot plate (IKA), dan vakum (DOA-P504-BH).

\section{Metode Penelitian}

(a) pembuatan serbuk kulit buah manggis dengan ukuran tertentu, (b) Pembuatan Ekstrak Etanol 70 \% kulit buah manggis, (c) Uji Kualitatif Senyawa Fenolik dengan $\mathrm{FeCl}_{3}$, uap amoniak, $\mathrm{AlCl}_{3}$, Folin Chiucalteau, dan Tanin, (d) Uji kuantitatif kadar polifenol total dengan metode Folin Ciocalteau, (e) Analisis data dengan kurva standar regresi linier $\mathrm{y}=\mathrm{bx}+\mathrm{a}$ berdasarkan data absorbansi dan konsentrasi larutan kurva standar. Kemudian dari persamaan regresi linier yang diperoleh, dihitung kadar fenolik total dengan rumus (Kassim et al., 2012):

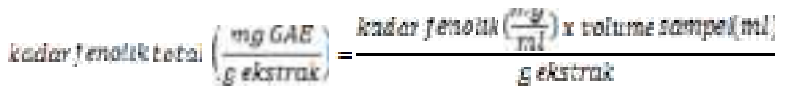

\section{Hasil Dan Pembahasan}

\section{Pengumpulan Bahan dan Penyerbukan Bahan}

Pengeringan kulit buah manggis dilakukan di dalam oven pada suhu $50^{\circ} \mathrm{C}$ Selama 1 minggu. Serbuk kulit buah manggis diayak menggunakan ayakan bertingkat sampai diperoleh serbuk dengan ukuran 30/50 mesh. Ukuran serbuk berpengaruh pada randemen ekstrak. Semakin besar luas permukaan serbuk simplisia maka semakin banyak sari yang dapat diambil. (Gambar 1). 


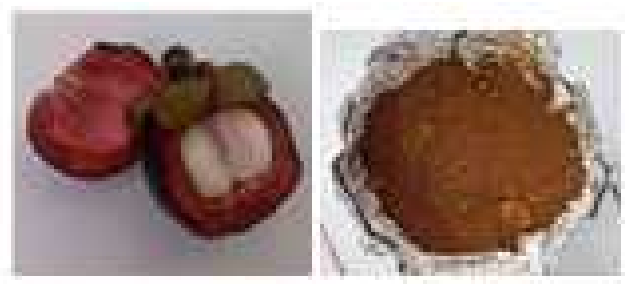

\section{Uji Kualitatif}

Hasil uji kualitatif ekstrak etanol $70 \%$ kulit buah manggis seperti dibawah ini (Tabel 1):

Gambar 1: Kulit buah manggis dan serbuk kulit buah manggis dari Martapura Kalimantan (Dokumentasi pribadi, 2015)

Tabel 1. Uji Kualitatif Senyawa Polifenol Ekstrak Etanol Kulit Buah Manggis Berdasarkan Perbedaan Asal Daerah

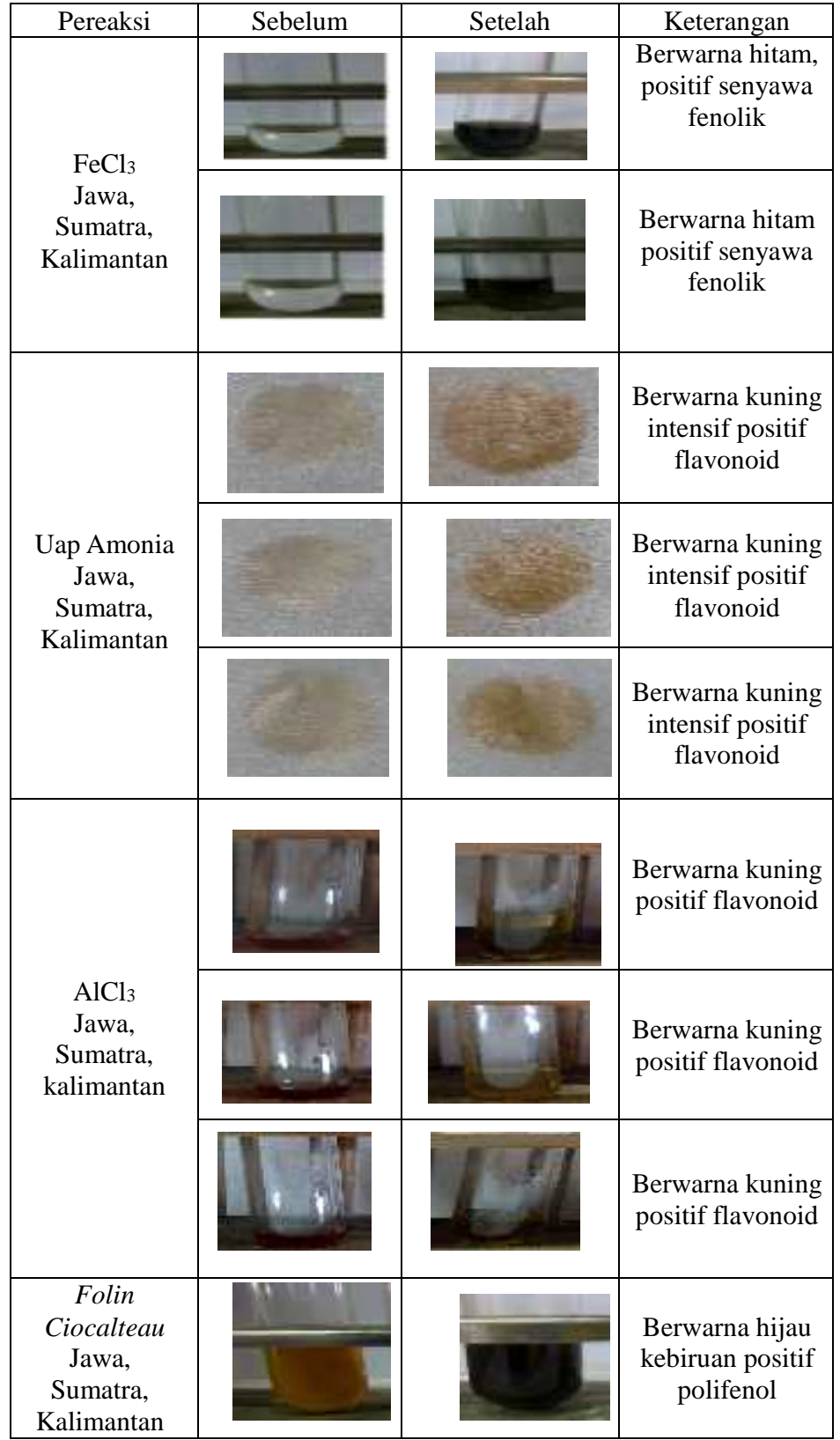


Hasil reaksi senyawa fenolik di dalam ekstrak etanol kulit buah manggis seperti dibawah ini: (Gambar 2)

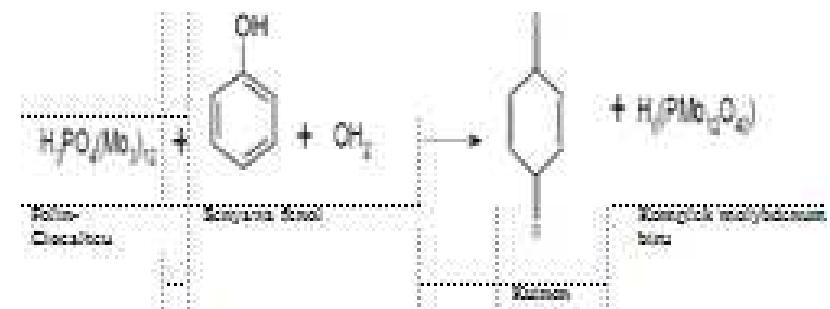

Gambar 2: Reaksi Folin Ciocalteau dengan senyawa fenol

\section{Penetapan Kadar Fenolik Total}

Hasil penelitian diperoleh Operating Time pada menit ke 61-69 dan panjang gelombang serapan maksimum pada $750 \mathrm{~nm}$. Hasil operating time dan panjang gelombang serapan maksimum digunakan untuk membuat kurva baku. Kurva Baku Asam Galat disajikan Gambar 3.

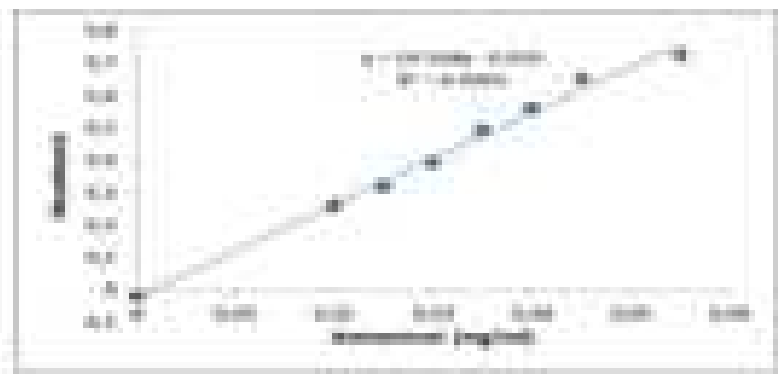

Gambar 3: Grafik hubungan antara konsentrasi dan larutan standard Asam Galat

\section{Uji Kuantitatif Fenolik Total}

Kadar fenolik total dilakukan secara spektrofotometri visibel dengan reagen Folin Ciocalteu (Zhang and Hamauzu, 2004). Metode ini didasarkan pada oksidasi gugus fenolik hidroksil oleh Folin Ciocalteu dalam suasana basa membentuk suatu kompleks molybdenum-tungstat (Mo-W) yang berwarna biru. Kadar fenolik total pada penelitian ini adalah sebagaimana disajikan pada Tabel II dan Gambar 4.

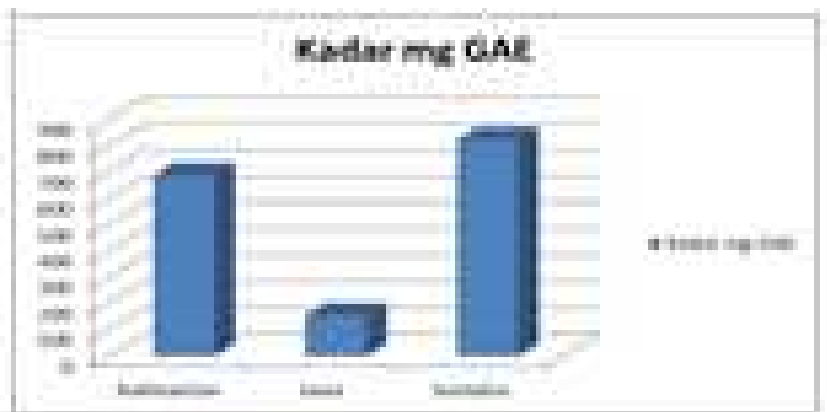

Gambar 4. Diagram rata-rata kadar fenolik total dari Jawa, Sumatra dan Kalimantan

Tabel 2. Kadar Fenolik Total Ekstrak Kulit Buah Manggis Variasi Asal Daerah

\begin{tabular}{|c|c|c|c|c|c|c|}
\hline Asal & Replikasi & $\begin{array}{l}\text { Bobot ekstrak } \\
(\mathrm{mg})\end{array}$ & Abs & $\begin{array}{l}\text { Kadar } \\
\mathrm{mg} / \mathrm{ml}\end{array}$ & $\begin{array}{c}\text { Kadar } \\
\text { fenolik total } \\
\text { (mg } \\
\text { GAE/g } \\
\text { ekstrak) }\end{array}$ & $\begin{array}{c}(\bar{X} \pm \text { LE }) \mathrm{mg} \\
\text { GAE/g ekstrak } \\
\text { CV } \%\end{array}$ \\
\hline \multirow{5}{*}{ Sumatra } & 1 & 50.1 & 0.707 & 0.0513 & 853.21 & \multirow{5}{*}{$\begin{array}{c}824.13 \pm 67.61 \\
8,21 \%\end{array}$} \\
\hline & 2 & 50.2 & 0.613 & 0.0447 & 741.96 & \\
\hline & 3 & 50.0 & 0.678 & 0.0493 & 821.58 & \\
\hline & 4 & 50.1 & 0.720 & 0.0522 & 868.18 & \\
\hline & 5 & 50.1 & 0.618 & 0.0450 & 748.43 & \\
\hline \multirow{5}{*}{ Jawa } & 1 & 150.1 & 0.372 & 0.0277 & 153.72 & \multirow{5}{*}{$\begin{array}{c}155.86 \pm 2.41 \\
1,95 \%\end{array}$} \\
\hline & 2 & 150.1 & 0.377 & 0.0280 & 155.68 & \\
\hline & 3 & 150.0 & 0.372 & 0.0277 & 153.83 & \\
\hline & 4 & 150.2 & 0.370 & 0.0275 & 152.84 & \\
\hline & 5 & 150.2 & 0.389 & 0.0289 & 160.28 & \\
\hline \multirow{5}{*}{ Kalimantan } & 1 & 150.1 & 0.385 & 0.0286 & 158.82 & \multirow{5}{*}{$\begin{array}{c}688,90 \pm 14,52 \\
1,98 \%\end{array}$} \\
\hline & 2 & 50,3 & 0,579 & 0,0423 & 700,788 & \\
\hline & 3 & 50,3 & 0,555 & 0,0406 & 671,455 & \\
\hline & 4 & 50,4 & 0,579 & 0,0423 & 700,788 & \\
\hline & 5 & 50,3 & 0,564 & 0,0412 & 682,561 & \\
\hline
\end{tabular}

Kadar fenolik total yang diperoleh menunjukkan bahwa kulit buah manggis dari Sumatra yang paling besar, kemudian Kalimantan dan paling kecil Jawa. Hal ini dipengaruhi oleh daerah tumbuh manggis, bahwa di Sumatra letak geografisnya sangat mendukung kandungan polifenol dalam tanaman manggis.

\section{KESIMPULAN}

Dari hasil penelitian diperoleh kadar senyawa fenol total dari Sumatra , Jawa dan Kalimantan yaitu (mg GAE/g ekstrak) 
:824.13 (mg GAE/g ekstrak); 155,86 (mg GAE/g ekstrak); 688,9 (mg GAE/g ekstrak).

\section{Daftar Pustaka}

Anonim, 2000, Parameter Standar Umum Ekstrak Tumbuhan Obat, Edisi I, Departemen Kesehatan Republik Indonesia, Jakarta.

Anonim, 2008, Farmakope Herbal Indonesia, Edisi I, Departemen Kesehatan Republik Indonesia, Jakarta.

Dungir, S. G., Katja, D. G., Kamu, V. S., 2012, Aktivitas Antioksidan Ekstrak Fenolik dari Kulit Buah Manggis (Garcinia mangostana L.), Jurnal MIPA Unsrat Online 1 (1) 11-15, Manado.

Factsheet, 2003, Fruits for the Future Mangosteen, University of Southampton, Southampton.

Ho CK, Huang YL, Chen CC, 2002, Garcinone E, a Xanthone derivative, has potent cytotoxic effects against Hepatocellular carcinoma cell lines, Planta Med, 68(11): 975-979.

Huang, D.B., dan Prior R.L., 2005, The Chemistry behind antioxidant capacity assay-reviews, J. Agric Food Chem, 53 : 1841-1856.

Kassim, J., Hazwan, H., Achmad, A., M Hazwani, D.n, Kim, S. and Safley, H. 2011, Penentuan Kandungan Fenol Total Tanin Terkondensasi dan Flavonoid dan Aktifitas Antioksidan Ektrak Uncaria gambir, Majalah Farmasi Indonesia, 22(1): 50-59

Lee, K.W., Kim, Y.J., Lee, H.J., and Lee, C.Y., 2003, Cocoa Has More Phenolic Phytochemical and A Higher Antioxidant Capacity than Teas and Red Wine, Journal of Agricultural and Food Chemistry, 51(25): 7292-7295.

Lih, G.C., Ling, L.Y., Ching, C.W., 2008, Antiinflammatory activity of mangostins from Garcinia mangostana, Food and Chemical Toxicology, 46 (2) : 688-693

Moongkarndi, P., Kosem, N., Luanratana, O., Jongsomboonkusol, S., Pongpan, N., 2004, Antiproliferative activity of Thai medicinal plant extracts on human breast adenocarcinoma cell line, Fitoterapia 75, 375-377.
Munekazu, I., Hideki, T., Toshiyuki, T., Asai, F., Yasuko, K., Ryoyu, S., dan Ken-Ichi, M., 2011, Antibacterial Activity of Xanthones from Guttiferaeous Plants against Methicillinresistant Staphylococcus aureus. Journal of Pharmacy and Pharmacology Journal of Pharmacy and Pharmacology, 48(8) : 861-865.

Nattaya, C., Ken, I.F., Tomihisa, O., Shigeo, N., Yasushi, O., 1996, Histaminergic and Serotonergic Receptor Blocking Substances from the Medicinal Plant Garcinia mangostana, Thieme Planta Medica, 62(5): 471-472.

Peka, A, Biesaga, M., dan Pyrzynska, K, 2010, Interaction of quercetin with copper : complexation, oxidation and reactivity towards radical. Biometals. 24:41-49.

Putra, INK, 2010, Aktivitas Antibakteri Ekstrak Kulit Buah manggis (Garcinia Mangostana L.) Serta Kandungan Senyawa Aktifnya, J Teknologi Industri Pangan, 21:15.

Weecharangsan, W., Opanasopit, P., Sukma, M., Ngawhirunpat, T., Sotanaphun, U., Siripong, P., 2006, Antioxidative and Neuroprotective Activities of Extracts from The Fruit Hull of Mangosteen (Garcinia mangostana Linn.), Med Princ Pract, 15, 281-287.

Zhang, D., dan Hamauzu, Y., 2004, Phenolic Compounds and Theirs Antioxidant Properties in Different Tissues of Carrots (Daucus carota L.), Food, Agriculture, and Environment, 2(1): 95-100 